\title{
THE INFLUENCE OF REMBRANDT ON COMPOSITION OF IMAGE IN MOVIES
}

\author{
Basma Khalil Ibrahim KHALIL *
}

Decoration Department, Faculty of Fine Arts, Alexandria University, Egypt

\begin{abstract}
There is no doubt that the Dutch plastic artist Rembrandt had his style separate from the artists of his time, and he influenced almost every field of Dutch art, and he was inspired by artists around the world and this influence was repeated and continued in no way in the history of art, and this influence extended until The present time includes the fields of arts, especially in cinema. For filmmakers, as well as generations of art enthusiasts, Rembrandt is the master of light and shadow, and his style of light distribution in painting has influenced many photographers and lighting designers in the history of cinema. In a study conducted to clarify the relationship between plastic art (photography and cinema or motion picture), some critics and filmmakers believed that without the paintings of the Dutch master of photography in the seventeenth century, many masterpieces of cinematography would not exist. Since the beginning of the fifteenth century, artists have used light as if it were a living element, invoking it and using it persuasively to create their own vision, light and shadow, essential components of the art of photography and cinematography, were given for the first time their true freedom by the Dutch artist Rembrandt and expanded with enthusiasm in The world of imagination, and his art was a source of inspiration for filmmakers in building the composition of the shots and the freedom of movement was given to the camera poetically through it, and he set the standard of the camera that it should be. Thus, Rembrandt, with his dramatic style, has inspired many generations in the history of art, and his influence extended to include many different branches of art, not just plastic art.

Keywords

The Influence, Rembrandt, Composition, Image, Movies.
\end{abstract}

\section{Introduction:}

\section{The Baroque Age: The Baroque Era}

Baroque art represents an expansion and progress in the art of the Renaissance and represents more than a shift in its principles; Italy has continued to be a target and source of inspiration for many artists throughout Europe, not only because of its great effects, but also because of great artists such as Caravaggio., Annibale Carracci and Bernini, who made Rome the most vibrant artistic center in Europe.

Baroque art is often used for the purposes of political and religious propaganda for the state, whether it is for the church or for the courtroom ... etc., and the colossal Louis XIV Palace in Versailles was one of the most complete examples of Baroque art that represents the unity of all the arts, a symphony Architecture in harmony with landscapes, photography with sculpture, furniture and metalwork in a unified and magnificent whole.

The Baroque era was for both the Netherlands and Spain a golden age of the arts, but while the conditions in Spain represented the continuation of ancient values with care - almost entirely -

\footnotetext{
* Corresponding author: finea-dean@ alexu.edu.eg
} 
in the hands of the Church, or in the care of the judiciary in the Netherlands, art in the Netherlands still preserved it. It is sponsored by the owner of money and influence. But at the same time it attracted the middle classes, who gathered paintings appropriate to the sizes and shapes of their middle homes.

\section{Art in Dutch Republic in Baroque Era:}

The golden age of the Netherlands coincided with the birth of political independence and the growth of economic prosperity, and the democracy of art was one of the most important factors that influenced the culture of the seventeenth century.

The issue of space in the painting was of great importance in Dutch art, and it produced extraordinary fruits not only for the great artists, but also for the minor artists who produced works of superior quality. As artists were interested in the canvas of the surfaces on which they perform their work, they also took interest in photographing landscapes and silent nature until they became the founders of that period.

There were two important centers of photography in the Golden Age of Dutch art in the first two decades of the seventeenth century, Haarlem * and Utrecht.

In Harlem, photographers realized and saw with clear eyes the landscapes in their local environment, worthy subjects, landscapes, life full of taverns and brothels, so they took advantage of them with pleasure, enthusiasm and ingenuity in the use of brushes, as did Frans Hals, who photographed the new customers in the city from merchants, teachers And dignitaries of high standing.

In Catholic Utrecht, the situation was different, as the artists were influenced by Italy especially landscape photographers - by the glow of the sun and the classic ties, and in particular Caravaggio, Utrecht's artists restored the Italian style that is concerned with the dramatic effects of light, the details of the human body and the materials rich in details and colors .

Dutch artists were interested in the optical effects of light (a prelude to the effect), as the Netherlands was the center of scientific experiments in the field of optics at this time, which made them influenced by Vermeer, which made them rave their works to transform from rough and rough works to quiet sober works similar to the unique works of Vermeer The artist Honthorst was truly cosmopolitan, he was a Catholic and had worked for Charles I in England before becoming the first court painter at The House of Orange in The Hague, and portraiture in Hunhorst's work is marked by sharpness and contraction, and distinctly different from that of Hans or works The same breakthrough as Rembrandt.

Each city in the Netherlands - Delft, Leyden, Dordrecht, Alkmaar, The Hague or Amsterdam 
... etc. It had its own artistic craftsmanship, there was not a single city that represented the capital of Dutch art, each city had its own strong individual traditions and ties of pride and selfesteem, but they all shared the magic works that fascinate their artists with raw materials and living elements.

\section{Artist Rembrandt:}

Rembrandt Harmenszoon van Rijn (1606-1669 AD) is an important joint of Dutch art. He settled in Amsterdam since 1631 AD. His personal works and paintings were distinguished by great expressive power, in addition to his scientific knowledge of the theories of light and shadows, as well as the noble human values of his personal thoughts and reflections on the fate of the human race, all these factors made him one of the top masters of global photography. He had a great affair during his life, and was influenced by the artists Car Vaggio and Rubens, but he used the effects of light and applied colors freely to justify the emotional and psychological state Rembrandt drew the boundaries of his life's atmosphere and psychological states through an unprecedented collection of very clear more than 100 personal portraits of him that reflected Rembrandt's early works in Leyden was his first mentor, Amsterdam photographer Pieter Lastman, through this artist, Rembrandt learned the general principles of Italian Baroque photography, especially Caravaggio's photography, who applied his concepts in the Netherlands and transmitted them through a photographer or Trucht. Perhaps the use of the young artist was also inspired. Rembrandt - with the aim of teaching him the highest values in painting, according to the view prevailing at this time and applied only in religious, historical, epic or mythological works.

Nevertheless, Rembrandt was - in particular - to demonstrate that these values can appear in any branch of art, and his passion and the acquisition of atmospheres and moral ideals with lessons made him remain constant throughout his history and artistic life. He treated his early works in a dramatic and emotional manner, in which sharp color transitions, clear defined lines, contrasts between light and shadow.

The heroic characters in his paintings wore contemporary clothing, sometimes like peasants, which makes them less perfect than Caravaggio's, as some of his early works appear provocatively rude and popular.

For Rembrandt, the Bible was a story of the past, present, and future. He was deeply religious, and this was embodied in his works. His insistence on showing the truth was extraordinary. He drew stripped models of clothes, scenes inspired by the Bible in great formations. By the year 1630 he moved to Amsterdam, where he rose. By refining the construction of his compositions, especially his handling of intermediate degrees between the intensity of light and darkness, he 
became at that time fully qualified to implement his paintings on a huge scale.

The first of his enormous collection of photographic work was Dr. Nicholas Tulip's 1632 Anatomy Lesson of Dr. Nicolaes Tulp became famous in Amsterdam, and then the drama increased further in the painting The Blinding of Samson in 1636.

Rembrandt obtained a mission from the Federal Governor of the Netherlands, to depict five scenes depicting the Passion of Christ, and in those paintings the features and characteristics of Rembrandt's style appeared in a very mature manner, and the general atmosphere in them the five paintings - was dramatic and reflected darkness and writing, in the painting The Descent from the Cross Descent from the Cross shows Rembrandt's full awareness of the formation of Rubens * of the same subject, but Rembrandt had his own sense of a faculty, in which Christ was imperfect flesh, but a wreckage of human body.

One of Rembrandt's most famous works is the painting The Night Watch, which is the largest ( $3.5 \times 4.5 \mathrm{~m})$ and he finished it in 1642, and it is the turning point and the culmination of his artistic work, in which Rembrandt shed light on a group of officers and soldiers in the composition Astonishingly dramatic history of color, movement, and harmonic contrast, Rembrandt's uniqueness is the unexplained elements like the glowing little girl to the left of the painting.

The year 1642 was the beginning of Rembrandt's financial dwindle and his failure to keep pace with the art of the age in lines and harmony, and perhaps also the diminution of his selfconfidence and his happiness, in this year his wife Saskia died, and the general atmosphere in his paintings became darker and lonely, and with the extra research it becomes clear that the painting Itself became richer, but at the same time more disturbed and more psychologically intense. Between 1640 and 1650, those years were the most prolific period of his life in production, and in his pencil works such as the painting The Hundred Guilder, which was as rich and complex as the rest. His other works, during the same period Rembrandt made hundreds of powerful drawings using a thick quill pen in almost lifelike compositions.

In the last two decades, Rembrandt began to simplify his compositions, rejecting the early principles of Baroque calling for the increase of classicism and with more stable and stable compositions, his use of colors and his dealings with light became more rich and subtle, this charged light of intense spirituality, it seems as if it comes from within the painting more than it might have. It is from an external source, the portraits drawn by people or for himself show vitality, clarity and strong faith to visualize and become an information and notification of the fate of the world and humanity.

As one of his greatest and most mysterious works, the painting known as The Jewish Bride, 
which he painted in 1667, which was traditional in theme or subject matter, and perhaps was simply a personal drawing of the wedding of two ordinary people, but celebrates the marriage as a break from the secrets of the Church It is the inauguration of shared and mutual love, in a way Rembrandt echoes the traditional description of the story Jacob and Rachel from the Bible. Rembrandt taught students during all the years of his work, and many of them responded to his point of view and vision, and showed loyalty and loyalty to that vision, and one of his most capable students and working with his views was Carel Fabritius, as he was the living link and link between Rembrandt and Vermeer.

There is no doubt that Rembrandt had his style separate from the artists of his time, and he influenced almost every field of Dutch art, and he was inspired by artists around the world and this influence has been repeated and continued in no way in the history of art, and this influence has extended to the present time to include areas The arts, especially the art of cinema

\section{The Influence of Rembrandt:}

For filmmakers, as well as generations of art enthusiasts, Rembrandt is the master of light and shadow, and his style of light distribution in painting has influenced many photographers and lighting designers in the history of cinema.

In a study conducted to clarify the relationship between plastic art (photography) and cinema or the motion picture, some critics and filmmakers believed that without the paintings of the Dutch master of photography in the seventeenth century, many of the masterpieces of cinematography would not exist.

From the beginning of the fifteenth century, artists used light as if it were a living element, invoking it and using it to persuade creation. Their own vision, light and shadow, essential components of the art of cinematography, were given for the first time their true freedom by the Dutch artist Rembrandt and expanded with enthusiasm in the world of imagination And freedom of movement was given to the camera poetically by him, it was Rembrandt who singlehandedly raised the stakes, and set the standard of the camera on which it should be. Some of Rembrandt's paintings could be referred to, such as Claudius Civelles' Conspiracy of Claudius Civilis in 1661, or his sponsors The Adoration of the Shepherds in 1646, as examples of artwork that generates a deep emotional response in the scenes through the game of light and shadow, the inspiring lighting adds the general atmosphere to the movement, so that the space extends and reaches towards the viewer, and at the same time the character's style and compositional position indicate the continuous movement in the changing frame. The result is animated drama without strong color, strict movement or superficial details.

Jack Cardiff and Gordon Willis - two Oscar-winning cinematographers - talked about 
Rembrandt's influence when they approached the issue of lighting. Jack Cardiff is the cinematographer for Black Narcissus and The Red Shoes, while Gordon Willis is the cinematographer for the Godfather trilogy. Or the Godfather trilogy, All the Presidents Men BBC's motion picture episodes included a 20-minute segment commenting on the work of Jack Cardiff where he discusses his love for artists such as Vermeer and Rembrandt, saying:

- I think if these artists were there today, they would be amazing photographers. "

Most artists use a 45-degree front light that is aimed at the face, creating a shadow under the nose. Rembrandt used the same lighting in many of his paintings.

Gordon Willis discusses lighting in The Godfather or The Godfather Part Two, and analyzes a number of key scenes from The Godfather Part One and Two that employ the Chiaroscuro technique derived from his study of Rembrandt's paintings in which Rembrandt used the dramatic use of light and shadow.

The following are some scenes from the movie The Godfather or The Godfather Part Two, these scenes in which the intense influence of cinematographer Gordon Willis Bermbrandt and his dramatic use of light and shadow and the movement of actors within the staff is noted.

The artist, Orson Welles, was also influenced by Brendt when he directed the movie Citizen Kane in 1941, and we find it in the scene when the film's hero returns from Europe to be celebrated by his colleagues. Welles arranged the characters in the staff as if they were in the characters' painting in an environment that is mostly Male, and there is a lonely female in the front, she looks as if she is looking to be among the men, but she is still marginalized as if if she moves a little, she comes out of the frame, light the staff from the front, the men stand around Kane (the hero) and the man who seems to be waiting for the paper Which Kane signs, this scene is a heroine in the middle and around him men turn their gaze towards him and seemingly seek a word from him, in Rembrandt's composition of The Night Watch - 1642, we see a similar arrangement of people, Captain Franz Banning Cocq in the middle. And lie by his side, and many onlookers hide in the shadows to the sides. The Rembrandt composition likewise contains a single female character that can be seen interspersed with the main characters, who appear out of place. The main difference in Welles's composition is that he dressed the main character in white with black standing next to him, unlike Rembrandt's composition.

\section{Results:}

1- The most important Dutch artists in the optical effects of light, as the Netherlands was the center of scientific experiments in the field of optics in the seventeenth century.

2- There is no doubt that Rembrandt had his style separate from the channels of his glory, and 
his influence extended to include many different branches of the arts, especially in cinema.

3- Rembrandt with his dramatic style has inspired many generations in the history of art and is considered the spade of light and shadow, and his style of light distribution in painting has influenced many photographers and lighting designers in the history of cinema.

4- Many cinematic masterpieces would not exist had it not been for the paintings of the Dutch master of photography Rembrandt.

5- The image king has wide-ranging possibilities for communication, with boundaries and superiority over the language of writing, just like music and visual arts, for it is not a regional language and it is not limited to a specific people or region, and the filmmakers have benefited from these endless possibilities in producing the cinematic image.

\section{Recommendations:}

1- The necessity to study the history of plastic art and above, and to raise awareness of this for all students of cinema arts, whether cinematography, cinematic landscape design and directing. 2- The importance of paying attention to the capabilities provided by the plastic arts, as this leads to the emergence of new cinematic images.

3- Awareness of how the overlap between plastic arts and cinematic films through research and deep understanding of the different techniques of artists in order to adapt them to serve the cinematic image and produce it as required. And obtaining an unexpected picture that breaks the boredom and stimulates the mind of the spectator, this overlap is often chosen according to the artist's vision and the subject prepared for him.

4- Spreading knowledge, information and awareness for those interested in working in the field of photography, design and cinematography of the importance of the image and spreading that culture and awareness related to the development taking place in the various fields of the film industry, whether for the preparation of specialists or for the public.

\section{References:}

1- David Piper-The illustrated History of Art - Bounty Books - 2000

2- Ghadeer ELMAYAH, TAKING ADVANTAGE OF THE TEXTILE INFLUENCES TO ADD THE DIMENSION OF CONCRETE TO THE WORKS OF THE ARTIST (CLAUDE MONET), International Journal of Multidisciplinary Studies in Art and Technology, Vol. 3, No. 1, 2020, pp. 12-13.

3- Amal Farag SOLIMAN, THE AESTHETIC AND COMMUNICATIVE VALUES OF ILLUSTRATIONS USED IN INFOGRAPHIC, International Journal of Multidisciplinary Studies in Art and Technology, Vol. 3, No. 1, 2020, pp. 14-23.

4- Sherif Massad Muhammad AREF, THE AESTHETIC AND FUNCTIONAL 
RELATIONSHIP OF THE MINERAL GATHERING IN ISLAMIC ART, International Journal of Multidisciplinary Studies in Art and Technology, Vol. 3, No. 1, 2020, pp. 24-28.

5- https://en.wikipedia.org/wiki/Rembrandt_lighting

6- http://en.wikipedia.org/wiki/Rembrandt

7- http://sensesofcinema.com/2009/feature-articles/orson-welles-painter/

8- http://www.digitalfilmarchive.net/clda/moving_image_arts/film_lesson plans/docume nts/ALLlessonplans.pdf

Received: August 18, 2020

Accepted: November 20, 2020 